\title{
HYGIENE PERORANGAN DAN RIWAYAT KONTAK DAN KEJADIAN KUSTA DI WILAYAH KERJA PUSKESMAS TANAH MERAH KABUPATEN BANGKALAN TAHUN 2016
}

\author{
Nur Mas'Ula, Nur Haidah, Marlik
}

\begin{abstract}
Leprosy is a chronic infectious disease, caused by bacteria (Mycobacterium leprae) that attack peripheral nerves, skin and other body tissues except central nervous system. It develops as a result of close physical contact with leprosy patients and poor condition of personal hygiene. The purpose of this study was to determine the risk of personal hygiene and contact history with the incidence of leprosy in Tanah Merah Health center in 2016.

This study used case control approach. The population of this research were leprosy patients in 2015 from Tanah Merah Health Center. The control population was non-leprosy patients living in Tanah Merah Health Center work area. Samples of this analysis were 22 cases and 22 controls and the research instruments were questionnaires and observation sheets. Data were analyzed by calculating the Odd Ratio.

The results showed that most respondents had low level of knowledge with the percentage of $56.8 \%$, the majority of the respondents had good personal hygiene $(54.5 \%)$ and the majority of the respondents had history of contact with leprosy patients by $52.3 \%$. the result of OR calculation shows that the personal hygiene $(\mathrm{OR}=4.67)$ and contact history $(\mathrm{OR}=1.73)$ were risk factors of leprosy incidence in Tanah Merah Health Center in 2016.

The community should maintain personal hygiene better and avoid sleeping together or close to the lepers to prevent the transmission of leprosy.
\end{abstract}

Keywords $\quad$ : Leprosy, Personal Hygiene, History of Contact

\section{PENDAHULUAN}

Penyakit Kusta adalah penyakit menular, menahun dan disebabkan oleh kuman (Mycobacterium leprae) yang menyerang saraf tepi, kulit dan jaringan tubuh lainnya kecuali susunan saraf pusat (Depkes RI, 2006:36). Kusta merupakan penyakit infeksius, tetapi derajat infektivitasnya rendah, waktu inkubasinya panjang, mungkin beberapa tahun, dan tampaknya kebanyakan pasien mendapatkan infeksi sewaktu masa anak-anak. Insidensi yang rendah pada pasien-pasien yang merupakan pasangan suami istri (kusta yang diperoleh dari pasangannya) memberikan kesan bahwa orang dewasa relatif tidak mudah terkena. Penyakit ini timbul akibat kontak fisik yang erat dengan pasien yang terinfeksi dan risiko ini menjadi jauh lebih besar bila terjadi kontak dengan kasus penderita kasus lepromatosa (kusta basah). Sekret hidung merupakan sumber utama terjadinya infeksi di masyarakat (Robin Graham Brown, 2005:24 dalam jurnal penelitian Yessita Yuniarasari, 2013).

Penyakit kusta terdiri dari dua jenis yaitu kusta kering dan kusta basah. Penyakit kusta (Morbus Hansen) bukan karena kutukan. Penyakit kusta merupakan penyakit kulit yang berkaitan dengan hygiene perorangan (Tantut Susanto, dkk., 2013). Hygiene perorangan dikarenakan perilaku hidup bersih dan sehat terutama kebersihan seseorang pada umumnya kurang mendapat perhatian diri sendiri. Hal tersebut dapat menyebabkan timbulnya penyakit kusta. Penyakit kusta dapat menyerang semua orang. Kuman tumbuh bersarang dikulit. Jika dibiarkan dapat merajalela ke bagian tubuh mana saja. Hidung jadi keropos, dan bagian tubuh anggota gerak rusak, karena sarafnya mati. Kulit tidak dapat merasakan apa-apa. Kulit terluka tanpa disadari (Koes Irianto, 2005).

Menurut Solomon, Daniel dan Moet dalam jurnal penelitian Andry Muharry (2013) menyatakan bahwa faktor risiko penyakit kusta diantaranya yaitu kontak serumah dengan penderita penyakit kusta, terdapat penderita kusta di lingkungan rumahnya/kontak tetangga, dan kondisi personal hygiene yang buruk. Hasil penelitian Yessita Yuniarasari (2013) menyatakan bahwa faktor risiko yang berhubungan dengan kejadian kusta yaitu tingkat pengetahuan, personal hygiene dan jenis pekerjaan. Hasil penelitian Maria Christiana (2008) menyatakan bahwa faktor risiko kejadian kusta yaitu jenis kelamin, riwayat kontak, pendidikan, 
status ekonomi, kepadatan hunian, personal hygiene. Hasil penelitian Andy Muharry (2007) menyatakan bahwa kondisi ekonomi keluarga rendah, kebersihan perorangan buruk.

Di Indonesia penderita kusta terdapat hampir diseluruh daerah dengan penyebaran yang tidak merata. Penderita kusta 90\% tinggal diantara keluarga mereka dan sisanya yang tinggal di rumah sakit kusta, koloni penampungan atau perkampungan kusta (WHO, 2011:391-397 ; Dalam target global WHO pada eradikasi kusta tahun (EKT) 2000 diharapkan prevalensi penyakit kusta kurang dari 1 per 10.000 penduduk (Widoyono, 2011:48).

Provinsi Jawa Timur pada tahun 2013 dengan jumlah penduduk 38,318,791 jiwa, jumlah penderita kusta sebesar 4.681 kasus dengan prevalensi 1,22 per 10.000 penduduk. Berdasarkan data dari Dinas Kesehatan Provinsi Jawa Timur tahun 2014, jumlah kasus baru penderita kusta sebanyak 3.983 penderita di seluruh Provinsi Jawa Timur dengan $38 \mathrm{Kota} /$ Kabupaten dimana kasus yang tertinggi yaitu di Madura sebesar 1529 kasus termasuk di Kabupaten Bangkalan. Tahun 2014 di Kabupaten Bangkalan, kasus baru penderita kusta mencapai 250 penderita kusta dengan prevalensi kusta sebesar 2,66 per 10.000 penduduk.

Tahun 2014 Di Puskesmas Tanah Merah Kabupaten Bangkalan mempunyai kasus kusta tertinggi kedua setelah Puskesmas Konang sebesar 23 penderita. Pada tahun 2015 menunjukkan bahwa Puskesmas Tanah Merah urutan kelima kasus penderita kusta setelah Puskesmas Geger sebesar 23 penderita.

Dari studi pendahuluan mendapatkan informasi oleh seksi bidang pemberantasan dan pengendalian penyakit bahwa di daerah Bangkalan tersebut memang kekurangan air, untuk membersihkan tubuh, mencuci pakaian pun tidak cukup, sehingga hygiene perorangan dan perilaku hidup bersih dan sehat mereka masih kurang.

\section{METODE PENELITIAN}

Penelitian ini termasuk jenis penelitian analitik dengan pendekatan case control yaitu pengumpulan data dimulai dari efek atau akibat yang telah terjadi. Kemudian dari efek tersebut ditelusuri ke belakang tentang penyebabnya atau variabel-variabel yang mempengaruhi akibat tersebut (Sukidjo Notoatmodjo, 2012).

Besar sampel penelitian ini adalah 22 orang penderita kusta dan 22 orang bukan penderita kusta yang memiliki karakteristik yang sama pada kasus. Teknik pengambilan sampel dengan menggunakan teknik simple random sampling dengan cara di undi. Responden akan di ukur tingkat pengetahuan, hygiene perorangan dan riwayat kontak melalui lembar kuesioner, lembar observasi dan wawancara. Selanjutnya hasil di analisis secara deskriptif dan menghitung odd ratio (OR) pada hygiene perorangan dan riwayat kontak.

\section{HASIL PENELITIAN}

Tabel 1: Risiko Hygiene Perorangan dan Kejadian Kusta di Wilayah Kerja Puskesmas Tanah Merah Tahun 2016

\begin{tabular}{ccccc}
\hline No. & & Hygiene Perorangan & Kasus & Kontrol \\
\hline \multirow{2}{*}{ 1. } & \multirow{2}{*}{ Kurang baik } & 14 & 6 \\
& & $(63,6 \%)$ & $(27,3 \%)$ \\
\hline \multirow{2}{*}{ B. Baik } & & 8 & 16 \\
& \multirow{2}{*}{ Total } & $(36,4 \%)$ & $(72,7 \%)$ \\
\hline & & 22 & 22 \\
& & $(100,0 \%)$ & $(100,0 \%)$ \\
\hline
\end{tabular}

Berdasarkan tabel 1 bahwa sebagian besar responden yang menderita sakit kusta memiliki hygiene perorangan yang kurang baik sebesar
$63,6 \%$ (14 orang), sedangkan yang tidak menderita sakit kusta sebagian besar memiliki hygiene perorangan yang baik sebesar $72,7 \%$ (16 orang). 
Hasil analisis dengan menghitung odd ratio (OR) didapatkan hasil nilai OR 4,67 berarti bahwa hygiene perorangan merupakan faktor risiko terjadinya penyakit kusta.

Berdasarkan tabel 2 bahwa sebagian besar responden yang menderita sakit kusta memiliki riwayat kontak dengan penderita kusta sebesar
$54,5 \%$ (12 orang), sedangkan yang tidak menderita sakit kusta sebagian besar tidak memiliki riwayat kontak dengan penderita kusta sebesar 59,1\% (13 orang). Hasil analisis dengan menghitung odd ratio (OR) didapatkan hasil nilai OR 1,73 berarti bahwa riwayat kontak merupakan faktor risiko terjadinya penyakit kusta.

Tabel 2: Risiko Riwayat Kontak dan Kejadian Kusta di Wilayah Kerja Puskesmas Tanah Merah Tahun 2016

\begin{tabular}{ccccc}
\hline No. & Riwayat Kontak & Kasus & Kontrol \\
\hline \multirow{2}{*}{1.} & \multirow{2}{*}{ Ya } & & 12 & 9 \\
& & $(54,5 \%)$ & $(40,9 \%)$ \\
\hline \multirow{2}{*}{ 2. Tidak } & & 10 & 13 \\
& \multirow{2}{*}{ Total } & $(45,5 \%)$ & $(59,1 \%)$ \\
\hline & \multirow{2}{*}{} & & 22 & 22 \\
& & & $(100,0 \%)$ & $(100,0 \%)$ \\
\hline
\end{tabular}

\section{PEMBAHASAN}

\section{Faktor hygiene perorangan dan kejadian kusta}

Personal hygiene (Kebersihan perseorangan) merupakan tindakan pencegahan yang menyangkut tanggung jawab individu untuk meningkatkan kesehatan serta membatasi menyebarnya penyakit menular terutama yang ditularkan secara kontak langsung (Nur Nasry Noor, 2006:24 dalam jurnal penelitian Silvia Indriani, 2014). Tujuan dari higiene perorangan adalah untuk meningkatkan derajat kesehatan, memelihara kebersihan diri, memperbaiki personal hygiene yang kurang, mencegah penyakit, menciptakan keindahan, dan meningkatkan rasa percaya diri (Wartonah, 2003 dalam jurnal penelitian Agsa Sajida, 2012). Penularan penyakit kusta belum diketahui secara pasti. Sehgal (2006) dalam buku Tantut Susanto, dkk (2013), mengemukakan bahwa mekanisme penularan $M$. leprae pada tubuh manusia diantaranya adalah melalui kontak langsung dengan penderita kusta, sekret pernafasan yang terinfeksi, melalui bersin, dan juga dapat ditularkan melalui tanah yang terinfeksi $M$. leprae.

Berdasarkan Tabel 1 diatas menunjukkan bahwa sebagian besar responden memiliki hygiene perorangan yang kurang baik sebesar $63.6 \%$,
Kondisi kerentanan individu yang kurang menjaga perilaku hidup bersih dan sehat dalam keluarga terutama keluarga dengan kusta akan mengakibatkan individu berisiko untuk terkena kusta lebih cepat.

Berdasarkan hasil analisis risiko dengan menghitung Odd Ratio (OR) didapatkan hasil OR 4.67, artinya bahwa hygiene perorangan merupakan faktor risiko terjadinya penyakit kusta. Hygiene perorangan yang kurang baik memiliki risiko terkena penyakit kusta sebesar 4.67 kali lebih besar dibandingkan yang memiliki hygiene perorangan yang baik.

Hasil penelitian ini sejalan dengan hasil penelitian Yessita Yuniarasari (2013) yang menunjukkan bahwa personal hygiene (hygiene perorangan) yang buruk memiliki risiko 5,333 kali lebih besar terkena penyakit kusta dibandingkan dengan personal hygienenya yang baik.

Penyakit kusta merupakan penyakit kulit yang berkaitan dengan higiene perorangan (Tantut Susanto,dkk., 2013). Dampak yang akan timbul jika personal hygiene kurang baik yaitu adanya gangguan kesehatan yang diderita seseorang karena tidak terpeliharanya kebersihan perorangan dengan baik. Untuk menghindari penularan suatu penyakit, maka kebersihan diri sendiri lebih ditingkatkan. 


\section{Faktor riwayat kontak dan kejadian kusta}

Riwayat kontak adalah riwayat seseorang yang berhubungan dengan penderita kusta secara terus-menerus baik serumah maupun tidak serumah dalam jumlah waktu kontak yang lama (25 tahun). Penyakit kusta merupakan penyakit menular dan menahun yang disebabkan oleh kuman Mycobacterium leprae yang dapat menyerang semua bagian tubuh kecuali susunan saraf pusat. Penyakit ini timbul akibat kontak fisik yang erat dengan pasien yang terinfeksi ini menjadi jauh lebih besar bila terjadi kontak dengan kasus lepromatosa.

Berdasarkan tabel 2 menunjukkan bahwa sebagian besar responden memiliki riwayat kontak dengan penderita kusta sebesar 47.7 \% Seseorang yang memiliki riwayat kontak erat dengan penderita kusta dalam waktu yang lama kemungkinan besar dapat tertular penyakit kusta. Karena kulit dan saluran pernapasan dianggap jalan masuknya kuman ke tubuh manusia.

Berdasarkan hasil analisis risiko dengan menghitung Odd Ratio (OR) didapatkan hasil OR 1.73, artinya bahwa riwayat kontak merupakan faktor risiko terjadinya penyakit kusta. Seseorang yang mempunyai riwayat kontak dengan penderita kusta memiliki risiko terkena penyakit kusta sebesar 1.73 kali lebih besar dibandingkan seseorang yang tidak mempunyai riwayat kontak dengan penderita kusta.

Hasil penelitian ini sejalan dengan hasil penelitian Maria Christiana (2008) yang menunjukkan bahwa riwayat kontak dengan penderita kusta memiliki risiko 2.114 kali lebih besar bila dibandingkan dengan yang tidak memiliki riwayat kontak.

Dampak yang timbul akibat kontak dengan penderita kusta dalam waktu yang lama dan secara terus-menerus dapat menjadi penularan suatu penyakit. Karena penyakit ini timbul akibat kontak fisik yang erat dengan pasien yang terinfeksi ini menjadi jauh lebih besar bila terjadi kontak dengan kasus lepromatosa. Untuk mencegah penularan penyakit yaitu berperilaku hidup bersih dan sehat,tidak tidur sekamar dengan penderita kusta atau tidak tidur bersama penderita kusta atau tidak tidur berhimpitan dan segera berobat di pelayanan kesehatan dan meminum obat secara teratur sesuai petunjuk dokter.

\section{Kesimpulan}

1) Sebagian besar responden memiliki tingkat pengetahuan kurang baik $56,8 \%$;

2) Sebagian besar responden memiliki hygiene perorangan yang baik sebesar $54,5 \%$;

3) Sebagian besar responden memiliki riwayat kontak dengan penderita kusta sebesar 47,7 $\%$;

4) Hygiene perorangan memiliki faktor risiko 4,66 kali terjadinya penyakit kusta;

5) Riwayat kontak merupakan faktor risiko 1,73 kali terjadinya penyakit kusta.

\section{Saran}

a. Hygiene Perorangan

Menjaga hygiene perorangan melalui :

1) Cuci tangan pakai sabun setiap selesai $B A B$, sebelum makan, sesudah makan dan setiap selesai melakukan kegiatan

2) Menutup mulut dan hidung ketika batuk maupun bersin

3) Mandi sehari minimal $2 x$ sehari dengan menggunakan sabun

4) Tidak membiasakan bergantian barang milik pribadi

5) Memotong kuku/tidak memelihara kuku panjang

b. Riwayat Kontak

Tidak sering kontak dengan penderita kusta misalnya tidak tidur sekamar/tidak tidur bersama penderita kusta dan tidak tidur berhimpitan dengan penderita kusta. 


\section{DAFTAR PUSTAKA}

Bustan, M.N., 2006. Pengantar Epidemiologi. Jakarta, PT. Rineka Cipta.Cetakan Kedua:32-34

Christiana, Maria, 2008. Analisis Faktor Risiko Kejadian Kusta (Studi Kasus Di Rumah Sakit Kusta Donorojo Jepara). Universitas Negeri Semarang:21-27.

Depkes RI, 2006. Buku Pedoman Nasional Pemberantasan Penyakit Kusta. Jakarta, Depkes RI. Cetakan XVIII:9-11.

Djuanda, Adhi, 2007. IImu Penyakit Kulit dan Kelamin. Jakarta, FKUI. Edisi Kelima:73-87.

Indriani, Silvia, 2014. Faktor Risiko Yang Berhubungan Dengan Kejadian Kusta (Studi Kasus Di Wilayah Kerja Puskesmas Kunduran Blora Tahun 2012). Universitas Negeri Semarang.

Irianto, Koes, 2015. Memahami Berbagai Macam Penyakit: Penyebab, Gejala, Penularan, Pengobatan, Pemulihan, dan Pencegahan. Bandung, Alfabeta, cv:444-445.

Muharry, Andy, 2007. Faktor Risiko Kejadian Kusta.Sekolah Tinggi Ilmu Kesehatan Kuningan.

Notoatmodjo, Soekidjo, 2007. Kesehatan Masyarakat Ilmu dan Seni. Jakarta, PT Rineka Cipta. Cetakan Pertama.

2012. Metodologi Penelitian Kesehatan. Jakarta, PT Rineka Cipta. Cetakan Kedua.
Sajida, Agsa, 2012. Hubungan Personal Hygiene dan Sanitasi Lingkungan dengan Sanitasi Lingkungan dengan Keluhan Penyakit Kulit Di Kelurahan Denai Kecamatan Medan Denai Kota Medan Tahun 2012. Universitas Sumatera Utara.

Sugiyono, 2014. Metode Penelitian Kuantitatif, Kualitatif, dan $R \& D$. Bandung, Alfabeta, CV.

Supardi, S dan Surahman, 2014. Metodologi Penelitian Untuk Mahasiswa Farmasi. Jakarta, CV. Trans Info Media.

Susanto, Tantut, dkk., 2013. Perawatan Klien Kusta Di Komunitas. Jakarta, Trans Info Media.Cetakan Pertama:25-41.

Susila dan Suyanto, 2015. Metodologi Penelitian Retrospective/Ex Post Facto Case Control Causal Correlation. Klaten, Bossscript.

Widoyoko, E.P., 2014. Teknik Penyusunan Instrumen Penelitian. Yogyakarta, Pustaka Belajar. Cetakan ketiga.

Widoyono, 2011. Penyakit Tropis: Epidemiologi, Penularan, Pencegahan dan Pemberantasannya. Jakarta, Erlangga. Edisi Kedua:48.

Yuniarasari, Yessita, 2013. Faktor Risiko Yang Berhubungan Dengan Kejadian Kusta (Studi Kasus Di Wilayah Kerja Puskesmas Gunem Dan Puskesmas Sarang Kabupaten Rembang Tahun 2011). Universitas Negeri Semarang: 